\title{
Teachers' perceptions about the use of the Learning ePortfolio as learning and assessment tool in Mondragon Unibertsitatea
}

\section{Sirats SantaCruz, Nagore Ipiña, Eugenio Astigarraga}

Faculty of Humanities and Education, Mondragon Unibertsitatea, Spain.

\begin{abstract}
The aim of the present study is to analyse teachers' initial perceptions about the use of the Learning ePortfolio as the main learning and assessment tool in Early Years Education and Primary Education Degrees. This is a piece of a major longitudinal research being carried out in the Faculty of Humanities and Education in Mondragon Unibertsitatea. Results show that teachers are aware of the flexibility offered by the Learning ePortfolio to assess students' learning processes. Indeed, teachers think the Learning ePortfolio is a valuable tool for both students and teachers. However, there are still some outstanding issues to discuss with all the teachers involved in the use of the Learning ePortfolio. Conclusions drawn from this study show that the Learning ePortfolio constitutes a helpful and valuable tool for both students and teachers and it helps when carrying out formative assessment processes. Nevertheless, more training is needed to solve the gaps identified for its use.
\end{abstract}

Keywords: Learning ePortfolio; formative assessment; higher education. 


\section{Introduction}

Traditionally a portfolio was a tool which emerged from arts and used as a showcase for the best works. In educational contexts, the use of the portfolio began in the USA and in the UK (Alcaraz, 2016), not as a showcase but to collect experiences and reflect on them (HartnellYoung et al., 2007) as well as to organise, design and assess students' learning processes (Bahous, 2008). In Europe was not until the 90s that the portfolio arose in educational contexts (Alcaraz, 2016; López-Fernández, 2008). Precisely, much innovations carried out in the field with portfolios and ePortfolios have been associated to learning and assessment (Alcaraz, 2016; Pérez-Gómez \& Serván-Núñez, 2016). In Spain, where this study was carried out, the ePortfolio has been used since the beginning of the $21^{\text {st }}$ century in teaching and learning processes up to its capability to promote metacognitive development (Klenowski, 2004) and to widen learning experiences (Scully, O’Leary, \& Brown, 2018). In fact, the use of ePortfolios is becoming common in higher education, both in international contexts (Clark \& Eynon, 2009; Soto, Barquín, \& Fernández, 2016) and in Spain (Alcaraz, 2016; Cobos, López, \& Llorent, 2016).

Klenowski (2004) states that the ePortfolio can be used in five different ways: 1) summative assessment; 2) competence certification and candidate selection; 3) promotional use; 4) teaching and learning support; and 5) professional growth. In connection with the fourth use -the ePortfolio for teaching and learning support- some authors (Pérez-Gómez \& ServánNúñez, 2016; Scully et al., 2018) rename the ePortfolio as the Learning Portfolio because of the fact that learning and assessment could be fostered by its meaningful use.

As far as Learning Portfolios are concerned, Scully et al. (2018) differentiate between three types: 1) as process which is valuable for students to reflect on their learning development; 2) as product where students could showcase their learning process; and 3) as dual goal orientation which encompasses the previous two by including drafts and artefacts related to learning processes together with finished products.

In any case, it is not possible to envision a learning process without taking into account its assessment approach (Biggs \& Tang, 2011). Nowadays, there are many competing assessment approaches as Hill and Barber (in Siarova, Sternadel, \& Masidlauskaite, 2017, p. 34) state: summative assessment or assessment of learning, formative assessment or assessment for learning and assessment as learning among others. Hayward (2015) goes even further when stating that assessment is learning.

Reflection and continuous feedback are considered significant elements of learning processes (Siarova et al., 2017). McLaren (in Siarova et al., 2017, p. 63) conclude that "providing feedback to pupils [or students] brings positive results in supporting learning, teaching and assessment, and that it also brings useful evidence for [...] formative assessment purposes". And the latter is precisely related to the general objective of the ePortfolio as Klenowski, 
Askew and Carnell (in Scully et al., 2018, p. 2) claim: “[...] [the ePortfolio’s] overall goal is to facilitate and document learning and development over time”. This is why the ePortfolio has gained importance as an assessment system in higher education (López-Fernández, 2008). As the author states, the ePortfolio arise:

as a new way to conceive the assessment that offers the opportunity to design a different system, with a new tool, which facilitates the acquisition and pursuit of learning, through the new roles assigned for teachers and students (López-Fernández, 2008, p. 55).

Nonetheless, further research is needed according to various research studies (Arís \& Fuentes, 2016; Klenowski, 2004; Scully et al., 2018). More specifically, as Parker, Ndoye and Ritzhaupt (2012, p. 105) stress, studies of Learning ePortfolios in "[...] teacher preparation programs is an open-ended realm of research”. In this line, the main aim of this study is to open new insights into students' and teachers' perceptions about the use of the Learning ePortfolio as the main learning and assessment tool in Early Years Education and Primary Education Degrees.

To sum up and bringing it all together, at the Faculty of Humanities and Education from Mondragon Unibertsitatea (Basque Autonomous Community, Spain) an institution-wide Learning ePortfolio was implemented in the Early Years Education and Primary Education Degrees in 2017/2018 academic year. To start the process some training sessions with teachers and students where organised at the beginning of 2017/2018 in order to give teachers and students support in teaching and learning processes (Table 1). Moreover, a specific guide was created as a common reference for teachers and students. Both learning process and achievements are reflected in the students' ePortfolios, so the dual goal orientation Learning ePortfolio proposed by Scully et al. (2018) is being used (Table 1). Furthermore, students are the ones in charge of using their Learning ePortfolio for their own personal and professional development and teachers are responsible for guiding students in their learning process. So continuous feedback is needed and given to students, placing everyone in the formative assessment approach (Table 1).

Table 1. The Learning ePortfolio's approach in the Faculty.

\begin{tabular}{ccc}
\hline Usage & Type & Assessment approach \\
\hline $\begin{array}{c}\text { Teaching and learning } \\
\text { support }\end{array}$ & Dual goal orientation & Formative assessment \\
& & \\
\hline
\end{tabular}

Source: own elaboration. 


\section{Method}

\subsection{Context}

This ongoing longitudinal research is being carried out in the Faculty of Humanities and Education from Mondragon Unibertsitatea in the Early Years Education and Primary Education Degrees. As stated before, the Learning ePortfolio was introduced at the beginning of 2017/2018 academic year in the Faculty. The first study was carried out during this academic year (Figure 1) with first year students and their teachers. Conclusions were drawn from Study 1 (see SantaCruz, Ipiña, \& Astigarraga, 2018a, 2018b) and some changes were made in the Learning ePortfolio’s approach for 2018/2019 academic year. This paper focuses on what has been done during the first term of this academic year (Study 2). This second study is being carried out during 2018/2019 academic year (Figure 1) with first and second year students and their teachers.

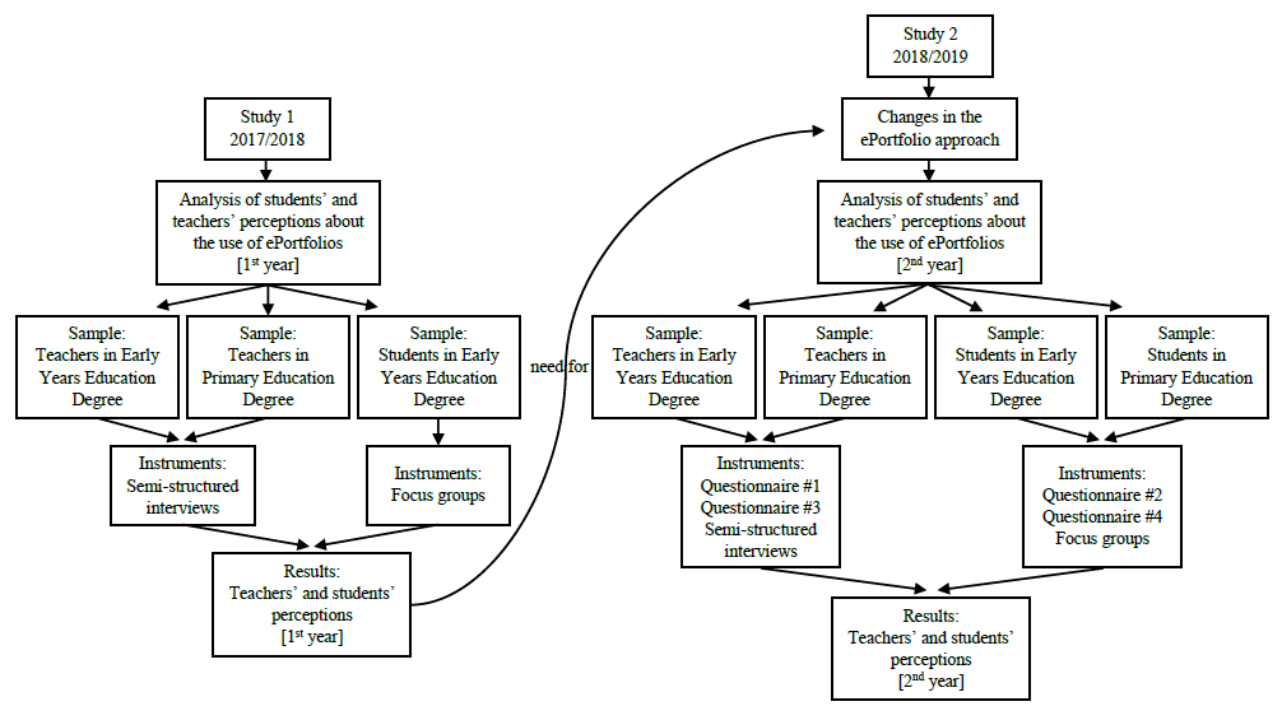

Figure 1. Studies, participants and research instruments. Source: own elaboration.

Two online open-ended questionnaires (Questionnaire \#1 and \#2 in Figure 1) have been designed ad hoc and delivered to teachers and students during the first term: a questionnaire for teachers and a questionnaire for students. Questionnaires \#3 and \#4 (Figure 1) will be delivered at the end of this academic year intending to compare pre-post answers. Semistructured interviews will be conducted with teachers and focus groups will be carried out with students during 2018/2019 (Figure 1). Thus, a data triangulation process will broaden validity to the analysis. 
The purposes of the teachers' questionnaire are to find out what use teachers have made to students' Learning ePortfolios so far and to identify their needs. In contrast, the aim of the students' questionnaire is to find out in what way students think their Learning ePortfolio will help them develop their personal and professional skills. The present paper is limited to teachers' perceptions. The questionnaire has been delivered to every teacher involved in the first and second years in Early Years Education and Primary Education Degrees ( $\mathrm{N}=50)$. A week was given to answer the online questionnaire and $60 \%$ replies were received.

\subsection{Data analysis}

Content analysis methodology has been followed in order to categorise teachers' perceptions about the use of the Learning ePortfolio as the main learning and assessment tool. A combination of etic -researchers' categories- and emic -non-expected categories identified in the corpus- has been made to identify the categories shown in Table 2.

Table 2. Categories and subcategories from Questionnaire \#1.

\begin{tabular}{ccc}
\hline \multicolumn{2}{c}{ Category } & Subcategories \\
\hline 1 & Use & Non-use \\
& & Follow-up \\
2 & Value & Validity \\
& & Satisfaction \\
3 & Needs & Not needs \\
& & Training \\
& & Students' technical need \\
& & Sharing approaches \\
\hline
\end{tabular}

Source: own elaboration.

The categories and subcategories were agreed upon by three researchers. The categories named as Use and Needs are researchers' categories, whereas Value is the non-expected one identified in the corpus.

\section{Results}

Findings in this study show that $40 \%$ of teachers who answered the questionnaire mentioned the use (Category 1 in Table 2) they have made of students' Learning ePortfolios so far. Results show that two groups of teachers were identified. While some teachers have not begun using students' Learning ePortfolios yet, others made connections between the Learning ePortfolio and the assessment process. In fact, some participants in the study are aware of the opportunities the Learning ePortfolio offers to assess students' learning processes. As Teacher 11 stated: 
I met my students one by one and I gave feedback to them on their first three artefacts uploaded into their Learning ePortfolio. Most of my students are now able to understand what an artefact is and how they could go more in depth in it from now on.

Furthermore, 20\% of teachers believe in the value of the Learning ePortfolio (Category 2 in Table 2). They stated that the Learning ePortfolio is a valuable tool for both teachers and students. Teacher 7 for example claimed the following after using it: "it is an outstanding tool for teachers to mentor and follow-up students' learning processes, as well as for students to self-regulate and to develop their own personal and professional skills".

$72 \%$ of participants who answered the questionnaire mentioned some personal needs (Category 3 in Table 2). There is a group of teachers who did not identify any special need during the first term of this academic year due to the fact that they used the guide created as a common reference to clarify their doubts. In addition, Teacher 21 stated the following:

I have not used students' Learning ePortfolios this term, but I would not have needed any help if I had had to use them because the guide explains quite clearly what the Learning ePortfolio is and how we should use it.

Nevertheless, the perception of most participants who have already used students' Learning ePortfolios is that there are some issues that need to be discussed and agreed. Teacher 12 claimed the following: "I do not know how to use students' ePortfolios". And Teacher 18 admitted that "my feeling is that I am really confused with the ePortfolio's approach". In addition, Teacher 5 affirmed that "we do not all understand in the same way the Learning ePortfolio's approach. Besides, not sharing a common view on the Learning ePortfolio could impact in a negative way on its use". In this line, teachers need some training as Teacher 26 requested: "I would need at least a half-morning training session about the Learning ePortfolio".

\section{Discussion and conclusions}

New insights into teachers' perceptions about the use and needs of the Learning ePortfolio for the first term of 2018/2019 academic year have been revealed in this paper. Firstly, results depict that participants began connecting the Learning ePortfolio with formative assessment processes. That is to say, participants are becoming aware of the opportunities the Learning ePortfolio offers to assess students’ learning processes as stated Alcaraz (2016), LópezFernández (2008) and Pérez-Gómez and Serván-Núñez (2016) among others.

Secondly, teachers released that the Learning ePortfolio is a helpful and valuable tool for both students and teachers. As demonstrated in the findings, students could self-regulate their own learning process and teachers could follow-up students' learning processes by giving 
them tailored feedback on what they are reading in their students' ePortfolios. Hence, students would be able to continue improving their learning processes while learning and this will contribute to formative assessment (Siarova et al., 2017).

Finally, there are some gaps that need to be discussed and agreed with all the teachers involved in the use of the Learning ePortfolio and for this purpose training and shared-spaces are needed. A training session was conducted at the beginning of this academic year trying to respond to a need identified in Study 1 in 2017/2018 as SantaCruz et al. (2018a, 2018b) concluded. Moreover, a guide was created explaining what the Learning ePortfolio is and how it should be used in Education Degrees in the Faculty. Even though, findings from this study have evidenced different views regarding the training needed: whereas some teachers believe they do not need any additional training, most of the participants are confused with the Learning ePortfolio's approach. So a new training programme for the next academic year should be designed in order to align the use of the Learning ePortfolio with the formative assessment process.

\subsection{Limitations and further research}

Conclusions must be viewed within the limitations of this study. In faith, the following limitations have been found in the present study. It is important to remind readers that this is only a piece of a wider longitudinal research. In this line, we have only focused on teachers' perceptions in this paper and students' perceptions are needed to understand the use of the Learning ePortfolio in the Faculty on a more specific way. Therefore, only a questionnaire has been delivered to collect data, so we are not able to triangulate data in this paper. But as shown in Figure 1, we foresee to have a wider and more specific picture of the use of the Learning ePortfolio in the Faculty by the end of this academic year.

\section{References}

Alcaraz, N. (2016). La Evaluación a través de Portafolios: ¿Una Ocasión para el Aprendizaje? Revista Iberoamericana de Evaluación Educativa, 9(1), 31-46. https://doi.org/10.15366/riee2016.9.1.002

Arís, N., \& Fuentes, M. (2016). La elaboración del portafolio a través del trabajo cooperativo y la autoevaluación. Revista Iberoamericana de Educación, 71(2), 9-28.

Bahous, R. (2008). The self-assessed portfolio: a case study. Assessment \& Evaluation in Higher Education, 33(4), 381-393.

Biggs, J., \& Tang, C. (2011). Teaching for Quality Learning at University: What the Student Does. London: McGraw-Hill Education.

Clark, J., \& Eynon, B. (2009). E-portfolios at 2.0: Surveying the field. Peer Review, 11(1), 18-23. 
Cobos, D., López, E., \& Llorent, M. (2016). Porpuesta de innovación didáctica con portafolios electrónicos en formato blog: Un caso de estudio en una universidad. Formación Universitaria, 9(6), 27-42.

Hartnell-Young, E., Harrison, C., Crook, C., Pemberton, R., Joyes, G., Fisher, T., \& Davies, L. (2007). Impact study of e-portfolios on learning. Retrieved from https://dera.ioe.ac.uk/1469/7/becta_2007_eportfolios_report_Redacted.pdf

Hayward, L. (2015). Assessment is learning: the preposition vanishes. Assessment in Education: Principles, Policy \& Practice, 22(1), 27-43. https://doi.org/10.1080/0969594X.2014.984656

Klenowski, V. (2004). Desarrollo de portafolios para el aprendizaje y la evaluación. Madrid: Narcea.

López-Fernández, O. (2008). Digital learner portfolio as a tool for innovating assessment in the European Higher Education Area. Interactive Educational Multimedia, 16, 54-65.

Parker, M., Ndoye, A., \& Ritzhaupt, A. . (2012). Qualitative Analysis of Student Perceptions of E-Portfolios in a Teacher Education Program. Journal of Digital Learning in Teacher Education, 28(3), 99-107.

Pérez-Gómez, A. I., \& Serván-Núñez, M. J. (2016). Naturaleza y sentido del portafolios educativo. In El portafolios educativo en Educación Superior (pp. 41-47). Madrid: Akal.

SantaCruz, S., Ipiña, N., \& Astigarraga, E. (2018a). La utilización del ePortfolio en los Grados de Educación Infantil y Primaria: estudio exploratorio del rol docente. In X. Carrera, F. Martínez Sánchez, J. L. Coiduras Rodríguez, E. Brescó Baiges, \& E. Vaquero Tió (Eds.), EDUcación con TECnología: un compromiso social. Aproximaciones desde la investigación y la innovación (pp. 803-805). Lleida: Edicions de la Universitat de Lleida. https://doi.org/https://doi.org/10.21001/edutec.2018

SantaCruz, S., Ipiña, N., \& Astigarraga, E. (2018b). Students' and teachers’ perceptions about the use of ePortfolios as learning tools in the Early Years Education Degree in Mondragon Unibertsitatea. RAPPORT, 3(1), 61-69.

Scully, D., O’Leary, M., \& Brown, M. (2018). The Learning Portfolio in Higher Education. A Game of Snakes and Ladders. Dublin: Dublin City University, Centre for Assessment Research, Policy \& Practice in Education (CARPE) and National Institute for Digital Learning (NIDL).

Siarova, H., Sternadel, D., \& Masidlauskaite, R. (2017). Assessment practices for 21 st century learning: review of evidence. NESET II report. Luxembourg: Publications Office of the European Union. https://doi.org/10.2766/71491

Soto, E., Barquín, J., \& Fernández, M. (2016). Portafolios electrónico y educativo: el eportafolios. In A. I. Pérez-Gómez (Ed.), El portafolios educativo en Educación Superior. Madrid: Akal. 